\section{ANALISIS KETERSEDIAAN LOKASI PEMUKIMAN BERBASIS MITIGASI LONGSOR}

\author{
Arif Sudarto, Westi Utami* \\ Sekolah Tinggi Pertanahan Nasional, Indonesia \\ Jl. Tata Bumi No. 5, Gamping, Sleman, Yogyakarta, Indonesia
}

Jurnal Pengembangan Kota (2021)

Volume 9 No. 2 (166-179)

Tersedia online di:

http://ejournal2.undip.ac.id/index.php/jpk DOI: 10.14710/jpk.9.2.166-179

\begin{abstract}
Abstrak. Pertumbuhan penduduk serta keterbatasan lahan untuk permukiman mengakibatkan sebagian masyarakat membangun permukiman pada lokasi rawan bencana. Penelitian ini bertujuan memetakan potensi lokasi permukiman berdasarkan peruntukan ruang serta aman dari ancaman longsor. Metode penelitian dilaksanakan melalui analisis spasial dengan melakukan overlay peta serta pemberian skoring dan pembobotan. Variabel fisik yang digunakan meliputi kemiringan tanah, drainase, erosi, penggunaan lahan, aksesibilitas jalan, aksesibilitas tempat penting dan kerawanan bencana longsor. Prioritas lokasi permukiman ditentukan berdasarkan kesesuaian secara fisik dan ketersediaan lokasi menurut rencana tata ruang wilayah (RTRW). Hasil analisis kesesuaian lokasi secara fisik untuk permukiman di Kecamatan Ngargoyoso menunjukkan terdapat 28,99\% area sesuai untuk pemukiman, 38,83\% sesuai bersyarat dan $32,18 \%$ tidak sesuai. Sementara berdasarkan ketersediaan lokasi untuk permukiman dan kesesuaian dengan RTRW, lokasi yang tersedia untuk permukiman dikelaskan menjadi lokasi tersedia (I) seluas 788,28 Ha dan lokasi tersedia (II) seluas 351,62 Ha. Pemetaan ketersediaan lokasi pemukiman diharapkan mampu memberikan arahan kepada masyarakat agar dapat bermukim pada wilayah aman dari bencana dan sesuai dengan RTRW.
\end{abstract}

Kata Kunci : Mitigasi Longsor; Pemetaan Pemukiman; Pemanfaatan Ruang

[Title: Mapping of Settlement Based on Landslide Mitigation]. Population growth and limited land supply for settlements have resulted in some communities building settlements in disaster-prone locations. This study aims to map the potential location of settlements in accordance with the designation of space and safe from disasters. The method used is through spatial analysis by overlaying the map as well as scoring and weighting. Physical variables used include soil slope, drainage, erosion, land use, road accessibility, accessibility to important places and landslide hazard. Furthermore, the location priority for settlements is determined based on the physical suitability and availability of the location according to the Regional Spatial Planning (RTRW). The results of the physical location suitability analysis for settlements in Ngargoyoso District showed that $28.99 \%$ of the area was suitable for settlements, $38.83 \%$ was conditional and $32.18 \%$ unsuitable. Meanwhile, based on the availability of locations for settlements and compliance with the RTRW, the available locations for settlements are classified into Available I locations covering an area of 788.28 hectares and Available Location II covering an area of 351.62 hectares. It is hoped that the mapping of the availability of residential locations will be able to provide direction to the community so that they can live in areas that are safe from disasters and in accordance with the RTRW

Keywords: Landslide Mitigation; Settlement Mapping; Utilization of Space

Cara Mengutip: Sudarto, Arif., \& Utami, Westi. (2021). Analisis Ketersediaan Lokasi Pemukiman Berbasis Mitigasi Longsor. Jurnal Pengembangan Kota. Vol 9 (2): 166-179. DOI: 10.14710/jpk.9.2.166-179

\section{PENDAHULUAN}

Kebutuhan masyarakat terhadap tanah untuk permukiman semakin meningkat seiring dengan pertumbuhan penduduk, hal ini membawa konsekuensi terhadap timbulnya berbagai permasalah permukiman (Maita \& Rahmawati, 2018; Nugraha dkk., 2014; Putra \& Pradoto, 2016). Beberapa permasalahan yang marak terjadi diantaranya ketidaksesuaian pemukiman dengan arahan pola ruang (Hilmansyah \& Rudiarto, 2015),

ISSN 2337-7062 @ 2021

This is an open access article under the CC-BY-NC-ND license (http://creativecommons.org/licenses/by-nc-sa/4.0/). - lihat halaman depan (C) 2021

*Email westiutami@stpn.ac.id

Diterima 27 Mei 2021, disetujui 30 November 2021 
pemukiman kumuh (Sadali dkk., 2019) maupun keberadaan pemukiman pada daerah rawan bencana (Utami dkk., 2019). Dalam beberapa kasus menunjukkan masyarakat seringkali membangun pemukiman tanpa memperhatikan kondisi kestabilan lereng, struktur batuan, kemiringan lereng maupun tingkat kerawanan bencana (Hasibuan \& Rahayu, 2017; Utami dkk., 2019). Hal inilah yang menjadi penyebab ketika terjadi bencana khususnya longsor (Ramlah dkk., 2020), korban jiwa maupun kerusakan dan kerugian yang harus ditanggung oleh masyarakat sangat tinggi (Alimohammadlou dkk., 2021; Badan Penanggulangan Bencana Daerah, 2018; Hadmoko dkk., 2017).

Longsor merupakan salah satu bencana yang sering terjadi di Indonesia (Suriadi dkk., 2013), dimana dalam kurun waktu 2014 hingga 2019 terdapat 2.766 kejadian dan mengakibatkan jumah korban hingga 662 kematian (Badan Penanggulangan Bencana Daerah, 2018), angka ini lebih tinggi dari korban yang diakibatkan bencana banjir maupun angin puting beliung. Tingginya korban jiwa dan kerugian akibat longsor ini menunjukkan mitigasi bencana di Indonesia masih perlu ditingkatkan (Zamroni dkk., 2020). Data Badan Penanggulangan Bencana Daerah (2018) juga menyajikan sebagian masyarakat Indonesia meliputi \pm 5 juta penduduk tinggal pada wilayah rawan tsunami, $\pm 1,2$ juta penduduk tinggal pada wilayah rawan erupsi gunung api, $\pm 63,7$ juta jiwa bermukim pada wilayah rawan banjir dan sebanyak $\pm 40,9$ juta jiwa tinggal pada area rawan longsor. Tingginya jumlah penduduk yang bermukim pada wilayah rawan bencana ini tentunya membutuhkan mitigasi agar ketika terjadi bencana jumlah risiko dapat dikurangi (Hamida \& Widyasamratri, 2019). Selain itu upaya evaluasi pembatasan dan pengaturan terhadap penggunaan dan pemanfaatan ruang pada wilayah rawan bencana sangat diperlukan agar wilayah yang tidak diizinkan untuk pemukiman dapat dibatasi (Qiu \& Zhang, 2011). Evaluasi kesesuaian penggunaan lahan pemukiman dengan kemampuan fisik lahan sangat diperlukan untuk merumuskan kebijakan pemanfaatan ruang serta pembangunan wilayah yang berkelanjutan (Rabbani dkk., 2021; Ustaoglu \& Aydınoglu, 2020).
Mitigasi bencana yang diwujudkan dalam perencanaan tata ruang berperan penting dalam memberikan arahan penggunaan tanah secara tepat (King dkk., 2016; Roy \& Ferland, 2015). Pengarusutamaan perencanaan dalam manajemen risiko bencana menjadi hal krusial dalam memberikan keamanan maupun ketahanan masyarakat (Saunders \& Kilvington, 2016). Konsep ini telah diimplementasikan oleh beberapa negara diantaranya Turki mengatur perencanaan tata kota agar pembangunan maupun investasi tidak dilakukan pada wilayah rawan bencana (Orhan, 2015). Perubahan iklim global serta ancaman bencana alam yang terjadi di Filipina maupun di Australia juga mendorong pemerintah untuk merumuskan regulasi pengarusutamaan pengurangan risiko bencana dalam perencanaan pembangunan (Gabriel dkk., 2021; Glavovic, 2010). Pasca tsunami yang melanda Chili, pemerintah menetapkan peraturan terkait mitigasi bencana, meskipun dalam implementasinya intrumen yang disusun maupun keterlibatan masyarakat masih lemah. Edyanto (2011) juga menyebutkan lemahnya instrumen dalam perencanaan tata ruang berbasis mitigasi bencana juga terjadi pada beberapa wilayah di Indonesia. Dalam implementasinya paradigma pengurangan risiko bencana di beberapa wilayah di Indonesia masih belum/kurang terintegrasi dengan regulasi RTRW (Ahdi, 2015; Akhmad, 2010).

Pendekatan perencanaan penggunaan tanah secara tradisional pada wilayah rawan bencana menempatkan pembangunan dan masyarakat pada kondisi berisiko tinggi. Dalam hal ini maka paradigma risk based planning approach/RBPA atau pendekatan perencanaan berbasis risiko menjadi hal krusial untuk mewujudkan pembangunan berkelanjutan dan ketahanan masyarakat. Kajian ini bertujuan memberikan inovasi dalam menyusun instrumen perencanaan penggunaan tanah untuk pemukiman berbasis risiko dengan menggunakan pendekatan aspek fisik yang berpengaruh pada kerawanan longsor digabungkan dengan kemampuan lahan serta daya dukung lingkungan yakni ketersediaan aksesibilitas. Beberapa persyaratan fisik yang perlu diperhatikan diantarnya yaitu kemiringan lereng, kemampuan fisik tanah, penggunaan tanah, aksesibilitas jaringan infrastruktur dan kerawanan 
terhadap bencana alam (Saragih, 2018). Selain itu, dalam penentuan lokasi permukiman perlu diketahui persyaratan permukiman yang aman dan sesuai dengan peruntukannya karena antara lingkungan, alam dan manusia mempunyai hubungan timbal balik, artinya segala sesuatu yang berhubungan dengan aktivitas manusia dipengaruhi oleh lingkungan begitupun sebaliknya (Ritung dkk., 2007).

Pemilihan lokasi permukiman berbasis kelas kesesuaian lokasi dan arahan RTRW ini diperlukan untuk memberikan arahan bagi masyarakat agar dapat membangun pemukiman pada kawasan yang sesuai peruntukannya. Salah satu metode yang dapat dilaksanakan adalah memadukan peta tematik yakni peta rawan bencana longsor, peta kondisi fisik serta peta tata ruang. Hasil analisis peta-peta tersebut diharapkan dapat menyediakan informasi kesesuaian lokasi untuk permukiman sebagai bahan pertimbangan masyarakat dalam memilih lokasi untuk permukiman yang aman dan sesuai dengan peruntukan ruangnya, serta memberikan masukan bagi pemerintah dalam rangka mengarahkan pembangunan permukiman pada lokasi yang diprioritaskan.

Kajian ini diawali dengan menyusun peta kesesuaian lokasi pemukiman dengan mendasarkan peta kerawanan bencana longsor, ketersediaan aksesibilitas, kemampuan lahan dan penggunaan tanah eksisting. Hal ini penting dilakukan agar perencanaan pemukiman yang disediakan aman dari bencana serta memiliki lingkungan yang mendukung. Sebagai upaya mensinkronkan dengan tata ruang maka pada sub kajian selanjutnya membahas tingkat kesesuaian ketersediaan lokasi pemukiman dengan peta rencana tata ruang. Pada sub pembahasan akhir, kajian ini menyajikan peta prioritas pembangunan pemukiman berdasarkan pada pendekatan risiko. Pemetaan potensi pemukiman ini bertujuan agar tersedia kawasan permukiman yang aman sebagai wujud penataan pertanahan sehingga tingkat risiko bencana dapat berkurang (Utami, 2014). Penyajian distribusi spasial lokasi ketersediaan pemukiman berdasarkan kelas kesesuaian ini diharapkan juga memberikan informasi kepada masyarakat agar tidak membangun pemukiman pada zona merah rawan longsor.

\section{METODE PENELITIAN}

Lokasi penelitian berada pada wilayah rawan longsor yakni di Kecamatan Ngargoyoso, Kabupaten Karanganyar dengan pertumbuhan penduduk sebesar 3,15\% setiap tahunnya (Badan Pusat Statistik, 2019). Sebagai Kawasan yang cukup berkembang, BPS memprediksi pada tahun 2032 jumlah penduduk dapat mencapai \pm 48.126 jiwa. Sementara mendasarkan pada Peraturan Daerah Nomor 19 Tahun 2019 tentang RTRW, alokasi peruntukan permukiman di Kecamatan Ngargoyoso hanya seluas $1.148 \mathrm{Ha}$. Pertumbuhan penduduk yang meningkat serta keterbatasan daya tampung lingkungan yang terbatas untuk permukiman berimplikasi pada semakin luasnya pemanfaatan lahan pada kawasan tidak sesuai maupun pemanfaatan ruang pada wilayah rawan bencana (Arief \& Pigawati, 2015). Data Badan Penanggulangan Bencana Daerah (2018) menyebutkan bahwa Kecamatan Ngargoyoso merupakan salah satu wilayah sangat rawan longsor, dimana selama 2 tahun yakni 2016 hingga 2018 terdapat 145 kejadian.

Penelitian ini menggunakan pendekatan spasial yakni mendasarkan pada gejala tertentu sehingga mampu menyajikan distribusi spasial dengan mendasarkan pada variabel-variabel yang telah ditentukan. Pengumpulan data dilakukan melalui interpretasi peta/citra, observasi lapang dan data sekunder. Teknik analisis data yang digunakan yaitu skoring dengan pemberian bobot/nilai pada setiap faktor-faktor tertentu dengan memberi bobot pada masing-masing parameter untuk menentukan tingkat kemampuan berdasarkan kriteria yang telah ditentukan (Farizki \& Anurogo, 2017). Sementara, overlay dilakukan dengan menampalkan beberapa peta tematik dalam rangkaian pengambilan keputusan secara spasial.

Sebagai upaya menentukan kesesuaian lokasi untuk permukiman terdapat tujuh variabel yang digunakan yaitu peta kemiringan lereng, drainase, erosi, penggunaan tanah yang diperoleh dari Kantor Pertanahan Kabupaten Karanganyar, peta aksesibilitas jaringan jalan diperoleh dari dinas PUPR, sementara aksesibilitas tempat penting diperoleh dari peta rupa bumi indonesia (RBI) dan hasil survei lapang, peta kerawanan bencana 
longsor diperoleh dari peta BPBD Kabupaten Karanganyar. Hasil analisis variabel tersebut disajikan dalam peta kelas kesesuaian lokasi permukiman. Selanjutnya lokasi prioritas untuk permukiman ditentukan berdasarkan lokasi yang sesuai dan tersedia untuk permukiman menurut arahan pola ruang RTRW. Analisis kelas ketersediaan lokasi dilakukan dengan overlay antara peta kelas kesesuaian lokasi, peta permukiman eksisting dan peta peruntukan pola ruang.

Peta-peta tematik pada setiap variabel tersebut kemudian dianalisis untuk memperoleh peta kelas kesesuaian lokasi permukiman. Dalam kajian ini digunakan skor dan bobot, skor diberikan untuk memberikan tingkat nilai pada setiap variabel, sementara pemberian bobot diberikan untuk membedakan tingkat pengaruh variabel-variabel terhadap kesesuaian lokasi untuk pemukiman. Penilaian bobot dalam kajian ini merujuk pada penelitian yang dilakukan Leng dkk. (2017); Luhukay dkk. (2019) dan dengan penyesuaian sehingga diberikan skala angka 1 sampai 3 karena kondisi wilayah tidak terlalu beragam, cakupan area tidak terlalu luas dan terbatas pada lingkup kecamatan. Selain memberikan skor nilai terhadap masing-masing variabel, dalam kajian ini juga diberikan bobot dengan kisaran angka 1 sampai 3, dimana semakin tinggi bobot maka semakin tinggi pengaruhnya terhadap kesesuaian lokasi permukiman. Bobot bernilai 3 berarti menunjukkan pengaruh tinggi sebagai contonhnya tingkat kerawanan longsor, bobot bernilai 2 berarti sedang dan bobot 1 berarti rendah. Penilaian skor diberikan pada angka 1 sampai 3 dimana semakin tinggi skor maka semakin tinggi pengaruhnya terhadap kesesuaian lokasi permukiman. Skor bernilai 3 berarti menunjukkan kriteria kesesuaian tinggi, skor bernilai 2 berarti kesesuaian sedang dan skor bernilai 1 berarti menunjukkan kriteria tidak sesuai. Klasifikasi kriteria bobot dan skor variabel kesesuaian lokasi untuk permukiman disajikan pada Tabel 1.

Nilai bobot setiap variabel tersebut dikalikan dengan nilai skor masing-masing kriteria variabel. Selanjutnya, hasil perkalian ini akan dijumlahkan untuk mendapatkan total harkat variabel kesesuaian lokasi untuk permukiman. Rumus yang digunakan untuk mendapatkan total harkat adalah sebagai berikut:

Harkat Total $=\mathrm{V} 1 * \mathrm{~b} 1+\mathrm{V} 2 * \mathrm{~b} 2+$ $+\mathrm{Vn} * \mathrm{bn}$

Keterangan:

V1 = Nilai skor variabel ke-1

$\mathrm{V} 2$ = Nilai skor variabel $\mathrm{ke}-2$

$\mathrm{Vn}=$ Nilai skor variabel ke- $\mathrm{n}$

b1 = Nilai bobot variabel ke-1

b2 = Nilai bobot variabel ke-2

$b n=$ Nilai bobot variabel ke- $n$

Tabel 1. Klasifikasi Kriteria Bobot dan Skor Variabel

\begin{tabular}{|c|c|c|c|c|}
\hline Variabel & Bobot & Klasifikasi & Kriteria & Skor \\
\hline \multirow[t]{3}{*}{ Lereng } & \multirow[t]{3}{*}{3} & $2-15 \%$ & $\begin{array}{l}\text { Kesesuaian } \\
\text { Tinggi }\end{array}$ & 3 \\
\hline & & $15-40 \%$ & $\begin{array}{l}\text { Kesesuaian } \\
\text { Sedang }\end{array}$ & 2 \\
\hline & & $>40 \%$ & Tidak Sesuai & 1 \\
\hline \multirow[t]{3}{*}{ Drainase } & \multirow[t]{3}{*}{1} & $\begin{array}{l}\text { Tdk Pernah } \\
\text { Tergenang }\end{array}$ & $\begin{array}{l}\text { Kesesuaian } \\
\text { Tinggi }\end{array}$ & 3 \\
\hline & & $\begin{array}{l}\text { Tergenang } \\
\text { Periodik }\end{array}$ & $\begin{array}{l}\text { Kesesuaian } \\
\text { Sedang }\end{array}$ & 2 \\
\hline & & $\begin{array}{l}\text { Tergenang } \\
\text { Terus } \\
\text { Menerus }\end{array}$ & Tidak Sesuai & 1 \\
\hline \multirow[t]{3}{*}{ Erosi } & \multirow[t]{3}{*}{1} & $\begin{array}{l}\text { Tidak Ada } \\
\text { Erosi }\end{array}$ & $\begin{array}{l}\text { Kesesuaian } \\
\text { Tinggi }\end{array}$ & 3 \\
\hline & & $\begin{array}{l}\text { Erosi } \\
\text { Sedang }\end{array}$ & $\begin{array}{l}\text { Kesesuaian } \\
\text { Sedang }\end{array}$ & 2 \\
\hline & & Erosi Tinggi & Tidak Sesuai & 1 \\
\hline \multirow[t]{3}{*}{$\begin{array}{l}\text { Penggunaan } \\
\text { Tanah }\end{array}$} & \multirow[t]{3}{*}{3} & $\begin{array}{l}\text { Tegalan, } \\
\text { Kebun }\end{array}$ & $\begin{array}{l}\text { Prioritas } \\
\text { Tinggi }\end{array}$ & 3 \\
\hline & & $\begin{array}{l}\text { Permukima } \\
\mathrm{n}\end{array}$ & $\begin{array}{l}\text { Prioritas } \\
\text { Sedang }\end{array}$ & 2 \\
\hline & & $\begin{array}{l}\text { Sawah/Wad } \\
\text { uk/ Hutan }\end{array}$ & $\begin{array}{l}\text { Tidak } \\
\text { Prioritas }\end{array}$ & 1 \\
\hline \multirow[t]{3}{*}{$\begin{array}{l}\text { Aksesibilitas } \\
\text { Jalan }\end{array}$} & \multirow[t]{3}{*}{3} & $0-100 \mathrm{~m}$ & $\begin{array}{l}\text { Berpotensi } \\
\text { Tinggi }\end{array}$ & 3 \\
\hline & & $100-200 \mathrm{~m}$ & $\begin{array}{l}\text { Berpotensi } \\
\text { Sedang }\end{array}$ & 2 \\
\hline & & $>200 \mathrm{~m}$ & $\begin{array}{l}\text { Kurang } \\
\text { Berpotensi }\end{array}$ & 1 \\
\hline \multirow[t]{3}{*}{ Aksesibilitas } & \multirow[t]{3}{*}{2} & $0-750 \mathrm{~m}$ & $\begin{array}{l}\text { Kesesuaian } \\
\text { Tinggi }\end{array}$ & 3 \\
\hline & & $750-1500 \mathrm{~m}$ & $\begin{array}{l}\text { Kesesuaian } \\
\text { Sedang }\end{array}$ & 2 \\
\hline & & $>1500 \mathrm{~m}$ & $\begin{array}{l}\text { Kurang } \\
\text { Sesuai }\end{array}$ & 1 \\
\hline \multirow[t]{3}{*}{$\begin{array}{l}\text { Kerawanan } \\
\text { Longsor }\end{array}$} & \multirow[t]{3}{*}{3} & $\begin{array}{l}\text { Kerawanan } \\
\text { Rendah }\end{array}$ & $\begin{array}{l}\text { Kesesuaian } \\
\text { Tinggi }\end{array}$ & 3 \\
\hline & & $\begin{array}{l}\text { Kerawanan } \\
\text { Sedang }\end{array}$ & $\begin{array}{l}\text { Kesesuaian } \\
\text { Sedang }\end{array}$ & 2 \\
\hline & & $\begin{array}{l}\text { Kerawanan } \\
\text { Tinggi }\end{array}$ & Tidak Sesuai & 1 \\
\hline
\end{tabular}


Langkah selanjutnya setelah menentukan harkat total adalah melakukan penentuan kelas kesesuaian lokasi untuk permukiman dengan menggunakan klasifikasi mendasarkan pada kerangka kerja food agricultural organization (FAO) 1967 dan Kerangka international finance corporation (2002) dengan dilakukan penyesuaian. Keadaan tingkatan dalam kelas didasarkan pada jenis pembatas atau jenis perbaikan yang ditunjukkan dalam kelas tersebut. Dalam hal ini peneliti mengambil 3 (tiga) tingkatan kelas kesesuaian yang disajikan pada Tabel 2 .

Tabel 2. Kelas Kesesuaian Lokasi Untuk Permukiman

\begin{tabular}{cl}
\hline Kelas & \multicolumn{1}{c}{ Tingkatan } \\
\hline I & $\begin{array}{l}\text { Sesuai Untuk Pembangunan Kawasan } \\
\text { Permukiman }\end{array}$ \\
II $\quad \begin{array}{l}\text { Sesuai Bersyarat Untuk Pembangunan } \\
\text { Kawasan Permukiman }\end{array}$ \\
III $\quad \begin{array}{l}\text { Tidak Sesuai Untuk Pembangunan } \\
\text { Kawasan Permukiman }\end{array}$ \\
\hline Sumber: FAO (1967) dalam Rumayardkk (2018)
\end{tabular}

Sumber: FAO (1967) dalam Rumayar dkk. (2018)

Setelah menentukan kriteria tingkatan kelas kesesuaian, kemudian menentukan besarnya interval kelas kesesuaian dengan rumus sebagai berikut:

Interval Kelas $=\frac{\text { Jml Harkat Mak }- \text { Jml Harkat Min }}{\text { Jumlah Kelas yang Dibuat }}$

Berdasarkan penghitungan jumlah harkat pada rumus di atas diperoleh jumlah harkat maksimum dengan nilai 48 dan jumlah harkat minimum dengan nilai 16 . Jumlah kelas yang akan dibuat dalam penelitian ini yaitu 3 kelas sehingga interval kelas yang diperoleh yaitu dengan nilai 10 . Selanjutnya, kelas kesesuaian lokasi untuk permukiman dapat ditentukan berdasarkan klasifikasi relatif kondisi fisik wilayah yaitu Kelas I (Sesuai) dengan rentang jumlah harkat 38-48, kelas II (Sesuai Bersyarat) dengan rentang jumlah harkat 27-37 dan yang terakhir kelas III (Tidak Sesuai) dengan rentang jumlah harkat 16-26.

Untuk menentukan prioritas pengembangan permukiman dilakukan dengan mengacu pada ketersediaan lokasi (Umar dkk., 2019). Analisis ketersediaan lokasi untuk permukiman dilakukan dengan melakukan overlay antara peta kelas kesesuaian lokasi, peta permukiman eksisting dan peta peruntukan kawasan berdasarkan RTRW Kabupaten Karanganyar Tahun 2013-2032. Hasil analisis ketersediaan lokasi diklasifikasikan menjadi tiga kelas ketersediaan yaitu tersedia I, tersedia II dan tidak tersedia. Prioritas pengembangan permukiman ditentukan berdasarkan wilayah dengan luas lokasi kelas tersedia I paling besar. Kriteria kelas ketersediaan lokasi untuk permukiman dapat dilihat pada Tabel 3.

Tabel 3. Kriteria Kelas Ketersediaan Lokasi Untuk Permukiman

\begin{tabular}{|c|c|c|c|}
\hline \multirow{2}{*}{$\begin{array}{c}\text { Kelas } \\
\text { Ketersediaan }\end{array}$} & \multicolumn{3}{|c|}{ Kriteria } \\
\hline & $\begin{array}{l}\text { Kesesuaian } \\
\text { Lokasi }\end{array}$ & $\begin{array}{c}\text { Kondisi Penggunaan } \\
\text { Eksisting }\end{array}$ & Peruntukan Pola Ruang \\
\hline Tersedia I & Sesuai & $\begin{array}{l}\text { Permukiman dan Non } \\
\text { Permukiman }\end{array}$ & Kawasan Permukiman \\
\hline Tersedia II & $\begin{array}{l}\text { Sesuai } \\
\text { Bersyarat }\end{array}$ & $\begin{array}{l}\text { Permukiman dan Non } \\
\text { Permukiman }\end{array}$ & Kawasan Permukiman \\
\hline Tidak & Sesuai, Sesuai & Permukiman dan Non & Kawasan Lindung dan Kawasan \\
\hline Tersedia & $\begin{array}{l}\text { Bersyarat dan } \\
\text { Tidak Sesuai }\end{array}$ & Permukiman & $\begin{array}{l}\text { Budidaya Non Kawasan } \\
\text { Permukiman }\end{array}$ \\
\hline
\end{tabular}

Sumber: Umar dkk. (2019) dengan Penyesuaian

Dalam penelitian ini kerangka pemikiran disajikan sebagaimana yang dapat dilihat pada Gambar 1. 


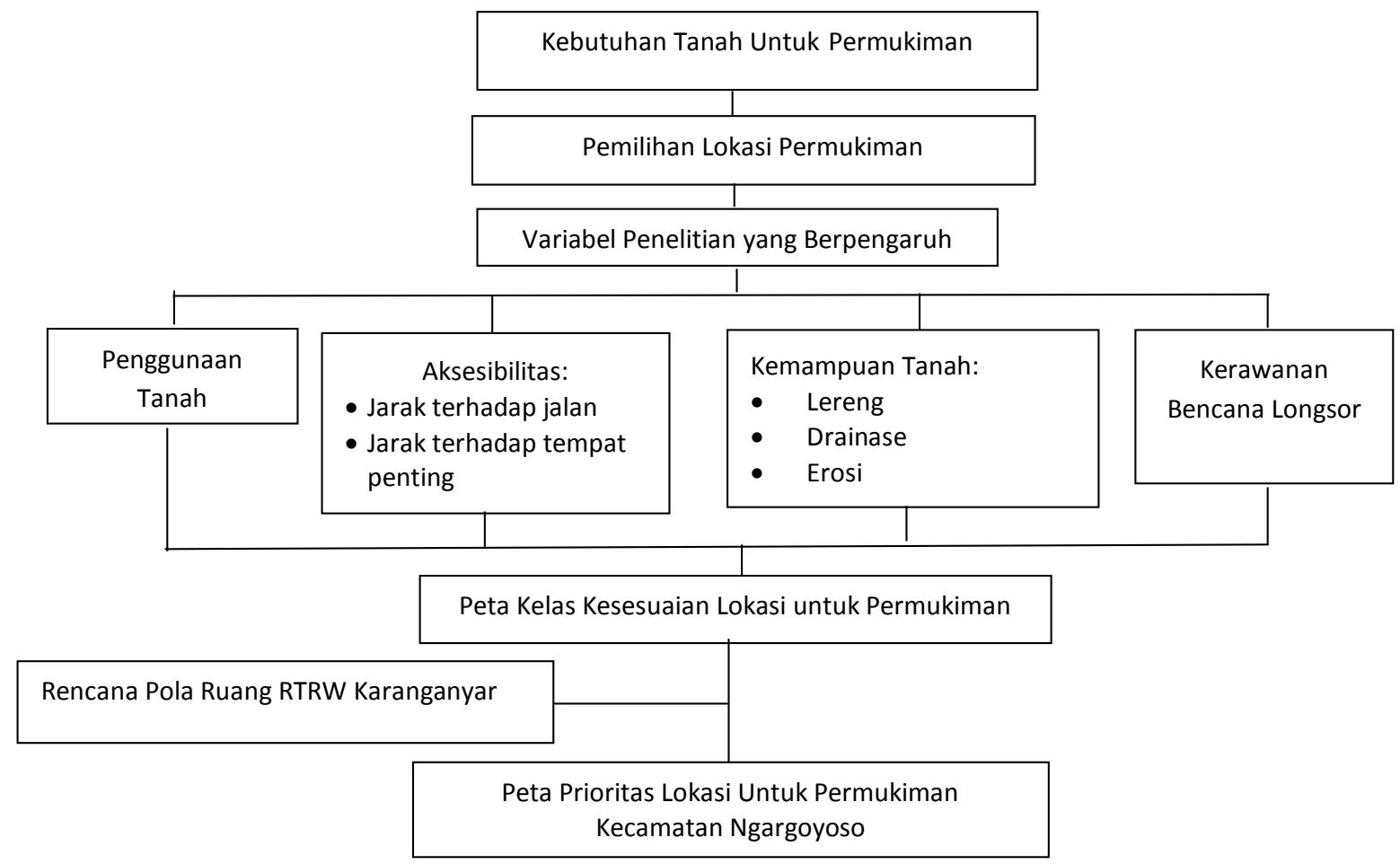

Gambar 1. Diagram Alir Penelitian

\section{HASIL DAN PEMBAHASAN}

Penentuan kelas kesesuaian lokasi untuk pemukiman dilakukan dengan cara overlay tujuh variabel sebagai rangkaian pengambilan keputusan secara spasial. Masing-masing variabel memiliki karakteristik pengaruh yang berbeda terhadap kesesuaian lokasi untuk permukiman. Berikut merupakan variabel penentu kesesuaian lokasi untuk permukiman di daerah penelitian

\section{a. Kemiringan/Lereng}

Kemiringan lahan/lereng suatu wilayah berpengaruh terhadap kesesuaian lokasi untuk pembangunan permukiman. Pembangunan permukiman relatif membutuhkan tempat yang datar. Lokasi dengan kemiringan tanah yang terjal cenderung menimbulkan potensi bencana longsor sehingga pembangunan permukiman pada lokasi tersebut sedapat mungkin dihindari. Data kemiringan lereng di lokasi penelitian merupakan data sekunder yang diperoleh dari Kantor Pertanahan Kabupaten Karanganyar. Kemiringan tanah/lereng di Kecamatan Ngargoyoso terdiri atas tiga kelas yaitu wilayah dengan kelerengan $2-15 \%$, $15-40 \%$ dan $>40 \%$ yang ditunjukkan pada Tabel 4 .

Tabel 4. Kriteria Kemiringan Lereng

\begin{tabular}{|c|c|c|c|}
\hline Lereng & Kriteria & Luas (Ha) & $\%$ \\
\hline $2-15 \%$ & $\begin{array}{l}\text { Kesesuaian } \\
\text { Tinggi }\end{array}$ & $1.365,75$ & 22,21 \\
\hline $15-40 \%$ & $\begin{array}{l}\text { Kesesuaian } \\
\text { Sedang }\end{array}$ & $2.497,20$ & 40,62 \\
\hline$>40 \%$ & Tidak Sesuai & $2.285,83$ & 37,17 \\
\hline
\end{tabular}

Tabel 4 menunjukkan bahwa lokasi dengan kelerengan $15-40 \%$ mendominasi di lokasi penelitian dengan luas $2.497,20 \mathrm{Ha}$ atau $40,62 \%$ dari luas keseluruhan wilayah. Wilayah dengan kelerengan 15-40\% memiliki kriteria kesesuaian sedang karena memiliki potensi bencana tanah longsor sehingga pembangunan permukiman pada wilayah ini perlu dilakukan dengan perlakuan tertentu misalnya menambah gaya penahan gerakan tanah dan memperkecil kemiringan lereng. Wilayah dengan kelerengan lebih dari $40 \%$ tidak sesuai untuk permukiman karena sangat berpotensi terhadap bencana longsor, sehingga dapat membahayakan keselamatan apabila tetap dipaksakan untuk pemukiman. Sementara pembangunan permukiman pada kelerengan 2- 
15\% diprioritaskan karena tidak memiliki ancaman bencana longsor, sehingga sesuai digunakan untuk pemukiman.

\section{b. Drainase}

Drainase menentukan daya serap air ke dalam tanah dan kemampuan mengalirkan limpasan air yang jatuh ke permukaan tanah (Saragih, 2018). Drainase yang baik mengindikasikan air mudah mengalir atau meresap dengan lancar, sementara pada drainase yang jelek mengindikasikan air sulit mengalir dan mudah tergenang. Kondisi drainase di Kecamatan Ngargoyoso ditunjukkan pada Tabel 5:

Tabel 5. Drainase di Kecamatan Ngargoyoso

\begin{tabular}{|c|c|c|c|}
\hline Drainase & Kriteria & Luas (Ha) & $\%$ \\
\hline $\begin{array}{l}\text { Tidak Pernah } \\
\text { Tergenang }\end{array}$ & $\begin{array}{l}\text { Kesesuaian } \\
\text { Tinggi }\end{array}$ & $6.133,42$ & 99,75 \\
\hline $\begin{array}{l}\text { Tergenang } \\
\text { Periodik }\end{array}$ & $\begin{array}{l}\text { Kesesuaian } \\
\text { Sedang }\end{array}$ & 0 & 0 \\
\hline $\begin{array}{l}\text { Tergenang } \\
\text { Terus } \\
\text { Menerus }\end{array}$ & $\begin{array}{l}\text { Tidak } \\
\text { Sesuai }\end{array}$ & 13,36 & 0,25 \\
\hline
\end{tabular}

Kondisi drainase di Kecamatan Ngargoyoso didominasi oleh wilayah dengan drainase tidak pernah tergenang dengan persentase 99,75\%. Artinya, pada wilayah tersebut memiliki kondisi drainase yang baik. Pembangunan permukiman sebaiknya dilakukan pada wilayah dengan sistem drainase yang baik, hal ini berpengaruh terhadap limpasan air yang jatuh ke permukaan dapat segera teralirkan sehingga mengurangi tingkat ancaman bencana banjir. Sementara pada wilayah tergenang terus menerus memiliki sistem drainase yang tidak baik, hal ini dipengaruhi oleh limpasan air yang jatuh ke permukaan sulit teralirkan dan meresap dalam tanah.

\section{c. Penggunaan Tanah}

Penggunaan tanah memiliki pengaruh besar dalam penentuan lokasi untuk pengembangan permukiman. Beberapa penggunaan tanah yang dapat diprioritaskan untuk permukiman diantaranya lahan kosong atau daerah yang belum terbangun dan diusahakan bukan pada kawasan lindung atau tanah pertanian yang beririgasi teknis. Berdasarkan hasil analisis maka klasifikasi penggunaan tanah di Kecamatan Ngargoyoso disajikan pada Tabel 6.

Tabel 6. Penggunaan Tanah Ngargoyoso

\begin{tabular}{|c|c|c|c|}
\hline $\begin{array}{c}\text { Penggunaan } \\
\text { Tanah }\end{array}$ & Kriteria & Luas (Ha) & $\%$ \\
\hline Kebun & $\begin{array}{l}\text { Prioritas } \\
\text { Tinggi }\end{array}$ & 690,97 & 11,23 \\
\hline Tegalan & $\begin{array}{c}\text { Prioritas } \\
\text { Tinggi }\end{array}$ & $1.309,65$ & 21,29 \\
\hline Permukiman & $\begin{array}{c}\text { Prioritas } \\
\text { Sedang }\end{array}$ & $1.150,45$ & 18,71 \\
\hline Hutan & $\begin{array}{c}\text { Tidak } \\
\text { Prioritas }\end{array}$ & $1.897,39$ & 30,85 \\
\hline Sawah & $\begin{array}{c}\text { Tidak } \\
\text { Prioritas }\end{array}$ & $1.085,66$ & 17,65 \\
\hline Waduk & $\begin{array}{c}\text { Tidak } \\
\text { Prioritas }\end{array}$ & 14,63 & 0,23 \\
\hline
\end{tabular}

Hasil analisis penggunaan tanah di Kecamatan Ngargoyoso menunjukkan wilayah hutan mendominasi dengan persentase $30,85 \%$ dari luas keseluruhan wilayah. Penggunaan tanah hutan dan waduk tentunya tidak diprioritaskan karena wilayah ini merupakan Kawasan konservasi yang tidak boleh terdapat permukiman di dalamnya. Khusus wilayah ini diupayakan tetap terjaga agar kelestarian hutan dan sumber air berkesinambungan. Pengembangan permukiman memiliki nilai rendah apabila dilakukan pada penggunaan tanah pertanian basah (sawah beririgasi teknis). Pengembangan permukiman pada tanah sawah tidak prioritas karena dapat mengakibatkan pengurangan lahan pertanian sehingga dapat mengganggu ketahanan pangan. Penggunaan tanah permukiman di Kecamatan Ngargoyoso merupakan lokasi terbangun dengan kategori perkampungan jarang. Pengembangan permukiman pada lokasi sudah terbangun akan menjadikan wilayah itu semakin padat sehingga kualitasnya semakin kurang baik (Farizki \& Anurogo, 2017). Penggunaan tanah tegalan dan kebun memiliki prioritas yang lebih tinggi untuk pengembangan permukiman karena kondisinya masih kosong dan mudah untuk dilakukan penataan sehingga kualitas permukiman akan semakin baik. 


\section{d. Aksesibilitas Jalan}

Faktor aksesibilitas sangat berpengaruh terhadap kesesuaian lokasi untuk permukiman. Kemudahan akses untuk mencapai lokasi permukiman menjadi daya tarik bagi seseorang untuk membangun tempat tinggal. Asumsinya, semakin dekat lokasi dengan jalan maka semakin berpotensi untuk dibangun tempat tinggal dan sebalikanya semakin jauh terhadap akses jalan maka potensinya semakin rendah. Kedekatan lokasi terhadap jalan diklasifikasikan dalam tiga kelas yaitu kelas I, kelas II dan kelas III. Penilaian klasifikasi ini dilakukan dengan melakukan buffer kedekatan lokasi terhadap jalan yaitu jalan kabupaten dan jalan desa. Kelas I merupakan lokasi yang dekat dengan jalan yaitu pada jarak 0-100 m. Kelas II yaitu lokasi yang tidak terlalu jauh dengan jalan yaitu pada jarak 100-200 m. Sedangkan kelas III yaitu lokasi yang jaraknya jauh dari jalan yaitu pada jarak lebih dari $200 \mathrm{~m}$. Kelas akses jalan di lokasi penelitian dapat dilihat pada Tabel 7.

Tabel 7. Kelas Akses Jalan Kecamatan Ngargoyoso

\begin{tabular}{|l|l|r|c|}
\hline \multicolumn{1}{|c|}{$\begin{array}{c}\text { Kelas Akses } \\
\text { Jalan }\end{array}$} & \multicolumn{1}{|c|}{ Kriteria } & Luas (Ha) & $\%$ \\
\hline $\begin{array}{l}\text { Kelas I } \\
(0-100 m)\end{array}$ & $\begin{array}{l}\text { Berpotensi } \\
\text { Tinggi }\end{array}$ & $1.313,30$ & 21,35 \\
\hline $\begin{array}{l}\text { Kelas II (100- } \\
\text { 200m) }\end{array}$ & $\begin{array}{l}\text { Berpotensi } \\
\text { Sedang }\end{array}$ & 973,17 & 15,83 \\
\hline $\begin{array}{l}\text { Kelas III } \\
(>200 m)\end{array}$ & $\begin{array}{l}\text { Kurang } \\
\text { Berpotensi }\end{array}$ & $3.862,31$ & 62,82 \\
\hline
\end{tabular}

Lokasi dengan aksesibilitas tingkat I berpotensi tinggi untuk pengembangan permukiman karena kemudahan akses jalan berpengaruh terhadap efisiensi waktu sehingga pencapaian lokasi menuju lokasi permukiman tidak membutuhkan jarak yang cukup jauh dan waktu yang lama. Lokasi dengan aksesibilitas tingkat II berpotensi sedang untuk pengembangan permukiman. Sementara lokasi dengan aksesibilitas tingkat III kurang berpotensi untuk pengembangan permukiman karena daya tarik pemilihan lokasi permukiman pada wilayah ini rendah sebagai akibat sulitnya aksesibilitas lokasi terhadap jalan dan lamanya waktu tempuh menuju lokasi permukiman.

\section{e. Aksesibilitas Tempat Penting}

Ketersediaan fasilitas umum dan tempat penting merupakan salah satu pertimbangan dalam pemilihan lokasi permukiman karena memegang peran penting dalam kemudahan pemenuhan kebutuhan, pelayanan pemerintahan, kesehatan dan pendidikan. Dilihat dari aspek lokasi, permukiman yang dekat dengan sarana fasilitas umum akan sangat memudahkan dalam hal efisiensi waktu. Selain itu, pengembangan permukiman pada lokasi yang dekat dengan tempat penting dan fasilitas umum akan mempengaruhi tingginya nilai tanah di lokasi permukiman. Kedekatan lokasi terhadap tempat penting diklasifikasikan dalam tiga kelas yaitu kelas I, kelas II dan kelas III. Penilaian klasifikasi ini dilakukan dengan melakukan buffer kedekatan lokasi terhadap tempat penting seperti kantor kecamatan, puskesmas, sekolah, pasar dan terminal. Kelas I merupakan lokasi yang dekat dengan tempat penting yaitu pada jarak 0-750 m. Kelas II yaitu lokasi yang tidak terlalu jauh dengan tempat penting yaitu pada jarak 750-1500 m. Sedangkan kelas III yaitu lokasi yang jaraknya jauh dari tempat penting yaitu pada jarak lebih dari $1500 \mathrm{~m}$. Kelas akses tempat penting di lokasi penelitian dapat dilihat pada Tabel 8.

Tabel 8. Kelas Akses Tempat Penting Kecamatan Ngargoyoso

\begin{tabular}{lllc}
\hline $\begin{array}{c}\text { Kelas Akses } \\
\text { Tempat } \\
\text { Penting }\end{array}$ & Kriteria & Luas (Ha) & $\%$ \\
\hline $\begin{array}{l}\text { Kelas I } \\
(0-750 m)\end{array}$ & $\begin{array}{c}\text { Kesesuaian } \\
\text { Tinggi }\end{array}$ & $2.500,02$ & 40,65 \\
Kelas II & Kesesuaian & $1.617,38$ & 26,30 \\
$(750-1500 m)$ & Sedang & & \\
Kelas III & Kurang & $2.031,35$ & 33,05 \\
$(>1500 \mathrm{~m})$ & Sesuai & & \\
\hline
\end{tabular}

Tabel 8 menunjukkan bahwa wilayah kelas I mendominasi dengan persentase $40,65 \%$ dari luas keseluruhan wilayah Kecamatan Ngargoyoso. Pada lokasi kelas I kedekatan lokasi terhadap tempat penting dan fasilitas umum memiliki aksesibilitas yang baik sehingga upaya pemenuhan kebutuhan dan pelayanan umum menjadi lebih mudah. Hal ini menunjukkan pengembangan permukiman pada lokasi kelas I memiliki kesesuaian yang tinggi. Selain itu, pembangunan permukiman pada lokasi kelas I tidak membutuhkan biaya lebih besar untuk membangun fasilitas umum baru. Pada lokasi kelas II kedekatan lokasi terhadap tempat penting dan fasilitas umum memiliki aksesibilitas lebih besar. 
Pada lokasi kelas III kurang sesuai untuk pengembangan permukiman karena aksesibilitas menuju fasilitas umum cukup jauh sehingga berpengaruh terhadap efisiensi waktu tempuh. Selain itu, biaya yang diperlukan untuk mengembangkan permukiman di lokasi ini juga lebih mahal karena harus membangun fasilitas baru.

\section{f. Kerawanan Bencana Longsor}

Tingkat kerawanan bencana longsor merupakan salah satu faktor yang mempengaruhi pemilihan lokasi untuk pengembangan permukiman di lokasi penelitian. Fungsi utama permukiman untuk tempat tinggal harus menyediakan lokasi yang aman dari bencana alam salah satunya adalah bencana tanah longsor. Wilayah yang jauh dari bencana dan kelerengan datar tentunya memberikan rasa aman dan keselamatan, sehingga sesuai untuk dibangun permukiman, sebaliknya wilayah dengan kerawanan bencana longsor tinggi memberikan ancaman terhadap keselamatan sehingga tidak sesuai untuk dibangun permukiman. Tingkat kerawanan bencana longsor di Kecamatan Ngargoyoso diklasifikasikan dalam tiga kelas ditunjukkan pada Tabel 9.

Tabel 9. Tingkat Kerawanan Bencana Longsor Kecamatan Ngargoyoso

\begin{tabular}{cccc}
\hline $\begin{array}{c}\text { Kerawanan } \\
\text { Longsor }\end{array}$ & Kriteria & Luas (Ha) & $\%$ \\
\hline $\begin{array}{c}\text { Kerawanan } \\
\text { Rendah }\end{array}$ & $\begin{array}{c}\text { Kesesuaian } \\
\text { Tinggi }\end{array}$ & $2.571,17$ & 41,82 \\
\hline $\begin{array}{c}\text { Kerawanan } \\
\text { Sedang }\end{array}$ & $\begin{array}{c}\text { Kesesuaian } \\
\text { Sedang }\end{array}$ & $3.148,15$ & 51,68 \\
\hline $\begin{array}{c}\text { Kerawanan } \\
\text { Tinggi }\end{array}$ & Tidak Sesuai & 399,46 & 6,50 \\
\hline
\end{tabular}

Wilayah dengan tingkat kerawanan bencana longsor rendah sebesar $41,82 \%$ dari luas keseluruhan. Wilayah ini berada pada lokasi dengan kerentanan gerakan tanah rendah dan kelerengan landai sehingga pengembangan permukiman pada wilayah ini memiliki kesesuaian tinggi dan tidak membahayakan keselamatan. Wilayah dengan tingkat kerawanan bencana sedang berada pada lokasi dengan kerentanan gerakan tanah dan kelerengan tingkat sedang. Pengembangan permukiman pada wilayah ini tidak membahayakan keselamatan apabila dilakukan dengan syarat mendirikan bangunan penahan gerakan tanah dan membuat terasering sehingga biaya yang dikeluarkan menjadi lebih besar. Wilayah dengan tingkat kerawanan bencana tinggi berada pada lokasi dengan kerentanan gerakan tanah tinggi dan kelerengan yang terjal sehingga tidak sesuai untuk pengembangan permukiman. Apabila masyarakat tetap membangun pada Kawasan ini maka tingkat risiko terhadap dampak bencana sangat tinggi dan tentunya membahayakan keselamatan.

\section{g. Identifikasi Kelas Kesesuaian Lokasi Permukiman}

Kelas kesesuaian lokasi untuk permukiman merupakan tingkatan yang mendeskripsikan secara jelas tentang gambaran kesesuaian lokasi untuk permukiman. Penilaian kesesuaian lokasi untuk permukiman dilakukan dengan menggunakan 7 variabel penentu kesesuaian lokasi untuk permukiman yaitu kemiringan tanah, drainase, erosi, penggunaan tanah, aksesibilitas jalan, aksesibilitas tempat penting dan kerawanan bencana longsor.

Peta kelas kesesuaian lokasi untuk permukiman diperoleh melalui analisis SIG, yaitu dengan mengoverlaykan ketujuh peta. Variabel-variabel tersebut diperoleh dari hasil interpretasi peta, data sekunder, dan survei lapangan. Masing-masing variabel diberi bobot berdasarkan pengaruhnya terhadap kesesuaian lokasi untuk permukiman. Variabel yang sangat berpengaruh diberi bobot 3, dan yang kurang berpengaruh diberi bobot 1 , sebelumnya setiap parameter diberikan harkat 1 sampai 3. Penentuan kesesuaian lokasi untuk permukiman ini diperoleh dengan menghitung harkat total variabel penentu kesesuaian lokasi untuk permukiman yaitu dengan menambahkan nilai hasil perkalian antara skor masing-masing variabel dengan bobot dari variabel penentu kesesuaian lokasi untuk permukiman. Setelah diketahui harkat total dari masing-masing satuan lokasi maka dapat diklasifikasikan kelas kesesuaian lokasinya. Untuk luasan pada masing-masing kelas kesesuaian di Kecamatan Ngargoyoso dapat dilihat dari Tabel 10. 
Tabel 10. Kelas Kesesuaian Lokasi Permukiman di Kecamatan Ngargoyoso

\begin{tabular}{|c|c|c|c|}
\hline $\begin{array}{c}\text { Kelas } \\
\text { Kesesuaia }\end{array}$ & Kriteria & Luas (Ha) & $(\%)$ \\
\hline Kelas I & Sesuai & $1.782,77$ & 28,99 \\
\hline Kelas II & $\begin{array}{l}\text { Sesuai } \\
\text { Bersyarat }\end{array}$ & $2.387,16$ & 38,83 \\
\hline Kelas III & Tidak Sesuai & $1.978,84$ & 32,18 \\
\hline \multicolumn{2}{|c|}{ Jumlah } & $6.148,78$ & 100 \\
\hline
\end{tabular}

Berdasarkan Tabel 10 diketahui bahwa kesesuaian lokasi untuk permukiman di Kecamatan Ngargoyoso didominasi oleh lokasi dengan kategori sesuai bersyarat dengan nilai presentase 38,83\% dengan luas 2.387,16 Ha. Kategori Sesuai Bersyarat merupakan lokasi yang mempunyai pembatas agak berat untuk permukiman. Faktor penghambat tersebut antara lain kondisi drainase atau saluran air yang tidak beraturan serta adanya bahaya erosi serta tanah longsor dengan potensi ancaman tingkat sedang serta aksesibilitas menuju tempat penting dan fasilitas umum relatif jauh. Lokasi dengan kategori Sesuai merupakan lokasi yang tidak mempunyai pembatas yang berat untuk dibangun permukiman dimana hanya mempunyai pembatas yang tidak berarti dan tidak berpengaruh terhadap pembangunan pemukiman. Kategori tidak sesuai merupakan lokasi dengan pembatas yang berat sehingga sulit bahkan tidak mungkin digunakan sebagai permukiman. Penyajian spasial distribusi tingkat kesesuaian lokasi permukiman berdasarkan 7 variabel disajikan sebagaimana pada Gambar 2

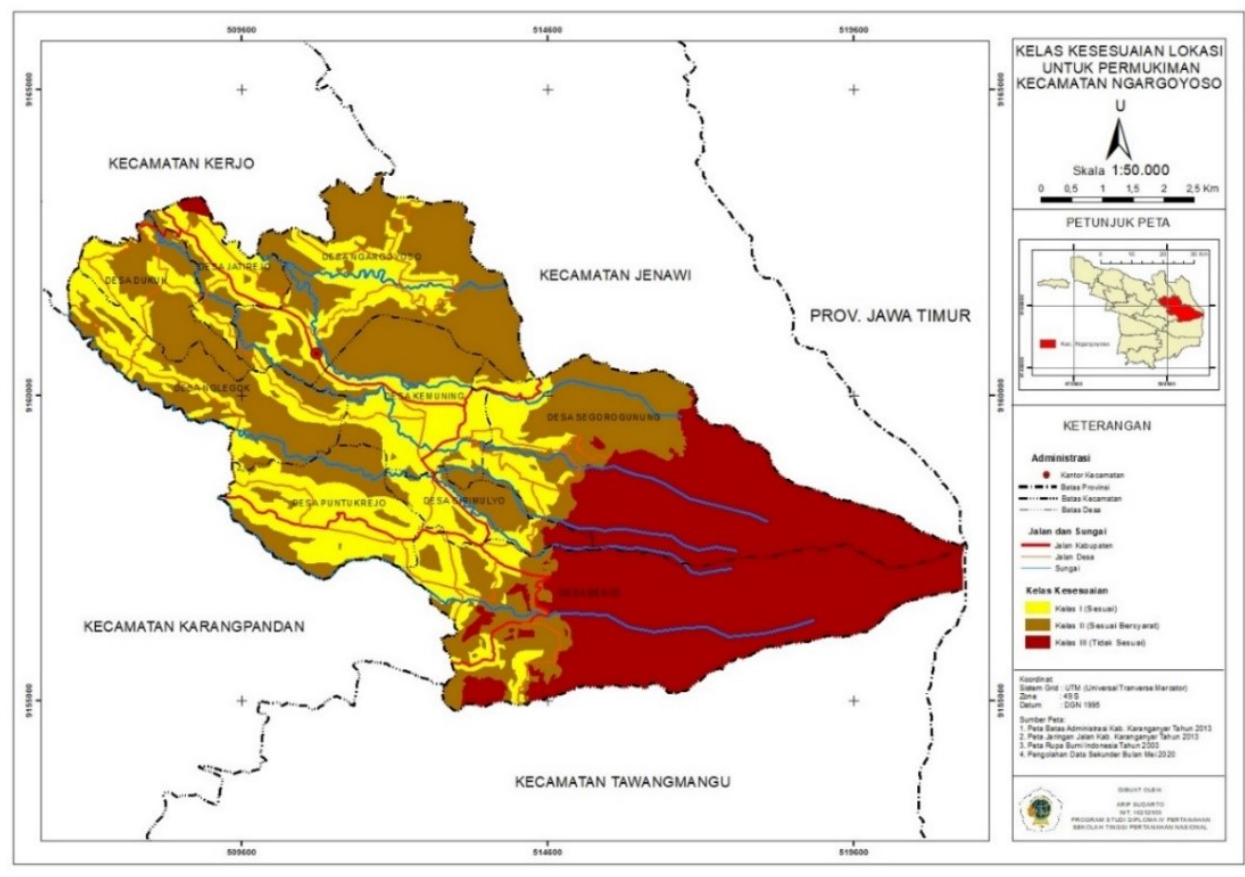

Gambar 2. Peta Kelas Kesesuaian Pemukiman Di Kecamatan Ngargoyoso

\section{h. Ketersediaan Lokasi Untuk Permukiman}

Ketersediaan lokasi untuk permukiman merupakan gambaran lokasi yang dapat digunakan untuk permukiman ditinjau dari kondisi permukiman eksisting, kesesuaian lokasi dan peruntukan ruang menurut RTRW. Peta kelas ketersediaan lokasi untuk permukiman di Kecamatan Ngargoyoso ditentukan berdasarkan tumpang susun (overlay) antara peta kelas kesesuaian lokasi untuk permukiman, peta kondisi permukiman eksisting dan peta rencana pola ruang RTRW Kabupaten
Karanganyar Tahun 2013-2032. Kelas ketersediaan ini digunakan sebagai acuan dalam pemilihan lokasi prioritas untuk permukiman. Hasil analisis ketersediaan lokasi untuk permukiman diklasifikasikan dalam tiga kelas yaitu tersedia I, tersedia II dan tidak tersedia yang disajikan pada Gambar 3. Luas wilayah pada masing-masing kelas ketersediaan lokasi untuk permukiman Kecamatan Ngargoyoso dapat dilihat pada Tabel 11. 
Tabel 11. Ketersediaan Lokasi Pemukiman

\begin{tabular}{lcc}
\hline \multicolumn{1}{c}{ Kelas Ketersediaan } & Luas (Ha) & (\%) \\
\hline Tersedia I & 788,28 & 12,82 \\
Tersedia II & 351,62 & 5,72 \\
Tidak Tersedia & 5008,88 & 81,46 \\
Jumlah & $6.148,78$ & 100 \\
\hline
\end{tabular}

Sementara distribusi spasial ketersediaan pemukiman disajikan pada Gambar 3. Berdasarkan Gambar 3 menunjukkan meskipun wilayah di Ngargoyoso cukup luas, namun terhadap wilayah tersebut banyak faktor pembatas yakni kemiringan lereng yang terjal dan tidak direkomendasikan untuk pemukiman. Sebagian besar wilayah di Desa Segorogunung dan Desa Berjo hampir memiliki lereng terjal hingga sangat terjal sehingga terbatas untuk digunakan sebagai pemukiman. Pada beberapa lokasi yang tidak dapat digunakan sebagai pemukiman di dalam RTRW difungsikan sebagai kawasan konservasi maupun kawasan lindung. Dalam konteks ini maka masyarakat harus memilih lokasi untuk pemukiman secara selektif. Distribusi ketersediaan pemukiman sebagaimana pada Gambar 3 diharapkan memberikan pedoman bagi masyarakat maupun pemerintah untuk memperhatikan lokasi yang tepat untuk pengembangan pemukiman dengan berdasarkan pada aspek fisik, aspek ketersediaan tanah maupun aspek kesesuaian ruang. Rabbani dkk. (2021) menyatakan evaluasi serta pemetaan potensi pemukiman ini selain melindungi masyarakat dari ancaman bencana juga mampu mendukung keberlanjutan lingkungan. Pemetaan potensi pemukiman dengan memperhatikan aspek lingkungan/fisik wilayah (Ustaoglu \& Aydınoglu, 2020), mengedepankan aspek keamanan dari ancaman longsor serta mepertimbangkan aksesibilitas lokasi harapannya dapat menjadi dasar dalam merumuskan arahan penggunaan dan pemanfaatan ruang yang tepat dan berkelanjutan.

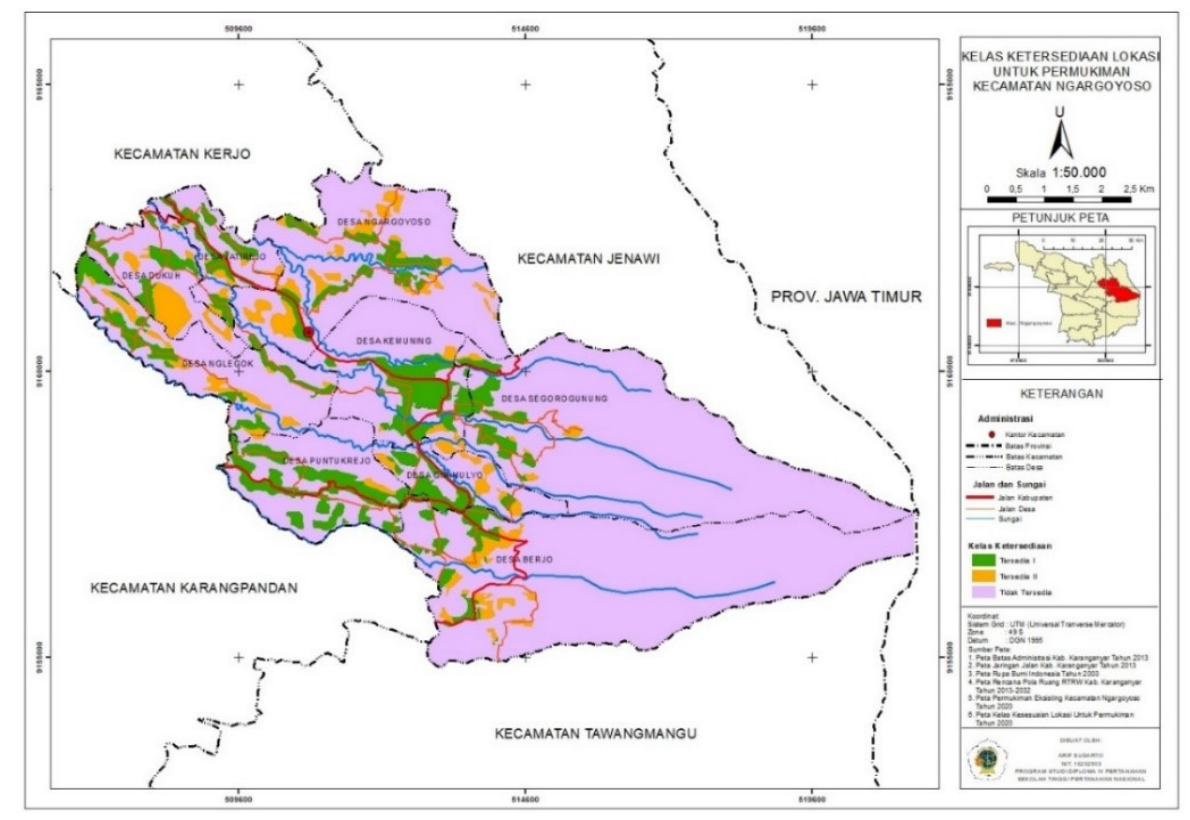

Gambar 3. Peta Kelas Ketersediaan Lokasi untuk Permukiman Kecamatan Ngargoyoso

\section{KESIMPULAN}

Bencana longsor sebagai salah satu bencana yang mematikan, menimbulkan kerusakan serta kerugian cukup tinggi memerlukan mitigasi struktural salah satunya dengan menyajikan distribusi spasial prioritas pengembangan permukiman yang aman dan sesuai dengan fungsi ruang. Keterbatasan data spasial potensi permukiman dengan mendasarkan analisis kesesuaian maupun kemampuan lahan berimplikasi pada tingginya kerugian maupun kematian saat terjadi bencana. Berdasarkan analisis kelas kesesuaian lokasi untuk permukiman di Kecamatan Ngargoyoso, luas wilayah dengan kategori sesuai untuk permukiman seluas $1.782,77 \mathrm{Ha}(28,99 \%)$, sesuai bersyarat seluas $2.387,16$ Ha $(38,83 \%)$, dan tidak sesuai seluas $1.978,84 \mathrm{Ha}$ (32,18\%). Tidak semua lokasi dengan kategori sesuai secara fisik sebagaimana tersebut di atas dapat 
diprioritaskan untuk pengembangan permukiman. Dalam penelitian ini hanya lokasi yang sesuai (RTRW dan kemampuan lahan) serta tersedia dapat diprioritaskan untuk pengembangan permukiman. Dalam kajian ini, ketersediaan lokasi untuk permukiman yang sesuai dan tersedia seluas $788,28 \mathrm{Ha}$ atau sebesar $12,82 \%$ dari luas keseluruhan wilayah Kecamatan Ngargoyoso. Sementara terhadap kawasan yang tidak diprioritaskan untuk permukiman sagatlah luas yang perlu diatur melalui regulasi/kerangka pengendalian pemanfaatan ruang. Celah ini tentu memerlukan studi lebih lanjut agar pengarusutamaan pengurangan risiko bencana dapat dilakukan mitigasi sejak awal.

Dalam rangka pengendalian fungsi ruang maka, penelitian ini merekomendasikan agar memperketat sistem pemberian izin pengembangan permukiman berdasarkan pada lokasi yang sesuai dengan tata ruang, aman dari bencana dan memperhatikan lahan yang tersedia. Sementara untuk menghindari tingginya jumlah korban akibat bencana longsor maka, perlu adanya sosialisasi kepada masyarakat agar dalam membangun permukiman mengacu pada arahan RTRW maupun wilayah yang aman dari ancaman longsor.

\section{UCAPAN TERIMA KASIH}

Penulis mengucapkan terimakasih kepada Sekolah Tinggi Pertanahan Nasional atas terselenggaranya penelitian ini. Ucapan terimakasih juga disampaikan kepada Bapak Slamet Muryono yang telah memberikan masukan terhadap perbaikan penelitian.

\section{DAFTAR PUSTAKA}

Ahdi, D. (2015). Perencanaan Penanggulangan Bencana Melalui Pendekatan Manajemen Risiko. Reformasi, 5(1), 13-30. Doi: https://doi.org/10.33366/rfr.v5i1.60

Akhmad, N. (2010). Tinjauan Regulasi Rencana Tata Ruang Kota Semarang Menggunakan Pendekatan Paradigma Pengurangan Resiko Bencana. Pandecta Research Law Journal, 5(2). Doi: $\quad$ https://doi.org/10.15294/pandecta. v5i2.2305

Alimohammadlou, Y., Tanyu, B. F., Abbaspour, A., \& Delamater, P. L. (2021). Automated Landslide Detection Model to Delineate The Extent of Existing Landslides. Natural Hazards, 107(2), 1639-1656. Doi: https://doi.org/10.1007/ s11069-021-04650-8
Arief, M., \& Pigawati, B. (2015). Kajian Kerentanan di Kawasan Permukiman Rawan Bencana Kecamatan Semarang Barat, Kota Semarang. Teknik PWK (Perencanaan Wilayah Kota), 4(2), 332-344.

Badan Penanggulangan Bencana Daerah. (2018). Daerah Rawan Bencana Kabupaten Karanganyar. Retrieved 22 Januari 2020 http://www.bpbd.karanganyarkab.go.id

Badan Pusat Statistik. (2019). Kecamatan Ngargoyoso Dalam Angka, katalog No. 3313070.1908. Karanganyar.

Edyanto, C. H. (2011). Analisa Kebijakan Penataan Ruang Untuk Kawasan Rawan Tsunami di Wilayah Pesisir. Jurnal Teknologi Lingkungan, 12(3), 319-331. Doi: https://doi.org/10.29122/ jtl.v12i3.1240

Farizki, M., \& Anurogo, W. (2017). Pemetaan Kualitas Permukiman dengan Menggunakan Penginderaan Jauh dan SIG di Kecamatan Batam Kota, Batam. Majalah Geografi Indonesia, 31(1), 39-45.

Gabriel, A. G., Santiago, P. N. M., \& Casimiro, R. R. (2021). Mainstreaming Disaster Risk Reduction and Climate Change Adaptation in Comprehensive Development Planning of the Cities in Nueva Ecija in the Philippines. International Journal of Disaster Risk Science, 12(3), 367-380. Doi: https://doi.org/10.1007/ s13753-021-00351-9

Glavovic, B. C. (2010). The Role of Land-Use Planning in Disaster Risk Reduction: An Introduction to Perspectives from Australasia. Australasian Journal of Disaster and Trauma Studies, 1, 1-22.

Hadmoko, D. S., Lavigne, F., \& Samodra, G. (2017). Application of a Semiquantitative and GISBased Statistical Model to Landslide Susceptibility Zonation in Kayangan Catchment, Java, Indonesia. Natural Hazards, 87(1), 437468. Doi: https://doi.org/10.1007/s11069-0172772-z

Hamida, F. N., \& Widyasamratri, H. (2019). Risiko Kawasan Longsor dalam Upaya Mitigasi Bencana Menggunakan Sistem Informasi Geografis. Pondasi, 24(1), 67-89. Doi: http://dx.doi.org/10.30659/pondasi.v24i1.499 7

Hasibuan, H. C., \& Rahayu, S. (2017). Kesesuaian Lahan Permukiman pada Kawasan Rawan Bencana Tanah Longsor di Kabupaten Temanggung. 
Teknik PWK (Perencanaan Wilayah Kota), 6(4), 242-256.

Hilmansyah, H., \& Rudiarto, I. (2015). Kajian Perkembangan dan Kesesuaian Lahan Permukiman Eksisting di Kecamatan Indramayu. Teknik PWK (Perencanaan Wilayah Kota), 4(1), 54-65.

King, D., Gurtner, Y., Firdaus, A., Harwood, S., \& Cottrell, A. (2016). Land Use Planning for Disaster Risk Reduction and Climate Change Adaptation: Operationalizing Policy and Legislation at Local Levels. International Journal of Disaster Resilience in the Built Environment, 7(2), 158172. Doi: https://doi.org/10.1108/IJDRBE-032015-0009

Leng, M., Tanesib, J. L., \& Warsito, A. (2017). Pemetaan Daerah Rawan Longsor dengan Penginderaan Jauh dan Sistem Informasi Geografis di Kabupaten Timor Tengah Utara Provinsi Nusa Tenggara Timur. Jurnal Fisika: Fisika Sains dan Aplikasinya, 2(1), 24-28. Doi: https://doi.org/10.35508/fisa.v2i2.546

Luhukay, M. R., Sela, R. L., \& Franklin, P. J. (2019). Analisis Kesesuaian Penggunaan Lahan Permukiman Berbasis (SIG) Sistem Informasi Geografi di Kecamatan Mapanget Kota Manado. SPASIAL, 6(2), 271-281.

Maita, I., \& Rahmawati, I. (2018). Sistem Informasi Pemetaan Potensi Daerah Pengembangan Kawasan Pemukiman Layak Huni Kota Pekanbaru. Paper presented at the Konferensi Nasional Sistem Informasi (KNSI) 2018.

Nugraha, Y. K., Nugraha, A. L., \& Wijaya, A. P. (2014). Pemanfaatan SIG untuk Menentukan Lokasi Potensial Pengembangan Kawasan Perumahan dan Permukiman (Studi Kasus Kabupaten Boyolali). Jurnal Geodesi Undip, 3(4), 50-59.

Orhan, E. (2015). The Consequences of Security Cognition in Post-Disaster Urban Planning Practices in the Case of Turkey. Natural Hazards, 76(1), 685-703. Doi: https://doi.org/10.1007/s11069-014-1497-5

Putra, D. R., \& Pradoto, W. (2016). Pola dan Faktor Perkembangan Pemanfaatan Lahan di Kecamatan Maranggen, Kabupaten Demak. Jurnal Pengembangan Kota, 4(1), 66-74. Doi: http://dx.doi.org/10.14710/jpk.4.1.66-74

Qiu, D., \& Zhang, J. (2011). Urban Residential Land Suitability Index System and its Comprehensive Evaluation-A Case Study of Wenzhou. Procedia Engineering, 21, 439-445. Doi: https://doi.org/10.1016/j.proeng.2011.11.203 6Get

Rabbani, G., Madanian, S., \& Daneshvar, M. M. (2021). Multi-Criteria Modeling for Land Suitability Evaluation of the Urban Greenbelts in Iran. Modeling Earth Systems and Environment, 7(2), 1291-1307. Doi: https://doi.org/10.1007/ s40808-020-01002-6

Ramlah, R., Hadmoko, D. S., \& Setiawan, M. A. (2020). Penilaian Tingkat Aktivitas Longsor di Sub-DAS Bompon. Media Komunikasi Geografi, 21(1), 12-26. Doi: http://dx.doi.org/10.23887/ mkg.v20i2.21360

Ritung, S., Wahyunto, Agus, F., \& Hidayat, H. (2007). Panduan Evaluasi Kesesuaian Lahan dengan Contoh Peta Arahan Penggunaan Lahan Kabupaten Aceh Barat. Bogor, Indonesia: Balai Penelitian Tanah dan World Agroforestry Centre (ICRAF).

Roy, F., \& Ferland, Y. (2015). Land Use Planning for Disaster Risk Management. Land Tenure Journal, 1-14.

Rumayar, G., Rogi, O. H., \& Rengkung, M. M. (2018). Analisis Kesesuaian Lahan Permukiman di Kecamatan Mantikulore Kota Palu. SPASIAL, 5(3), 386-393.

Sadali, M. I., Noviyanti, F., \& Andika, R. (2019). Asosiasi dan Distribusi Spasial Permukiman Kumuh di Kota Yogyakarta. Media Komunikasi Geografi, 20(2), 173-185. Doi: http://dx.doi.org/10.23887 /mkg.v20i2.21102

Saragih, C. V. S. (2018). Arahan Pemanfaatan Lahan Permukiman Berdasarkan Kelas Kemampuan Lahan dan Kawasan Rawan Bencana di Kabupaten Bogor. Paper presented at the Seminar Nasional Geomatika.

Saunders, W. S., \& Kilvington, M. (2016). Innovative Land Use Planning for Natural Hazard Risk Reduction: A Consequence-Driven Approach from New Zealand. International Journal of Disaster Risk Reduction, 18, 244-255. Doi: https://doi.org/10.1016/j.ijdrr.2016.07.002

Suriadi, A., Arsyad, M., \& Riadi, B. (2013). Potensi Resiko Bencana Alam Longsor (Potential Risk of Landslide Related to Extreme Weather in Ciamis Region, West Java). Jurnal IImiah Geomatika, 19(1), 57-63.

Umar, I., Dewata, I., \& Barlian, E. (2019). Konsistensi Rencana Tata Ruang Permukiman dan Arahan Kebijakan Pembangunan di Kabupaten Tanah Datar, Provinsi Sumatera Barat. Journal of 
Natural Resources and Environmental

Management, 9(2), 277-286. Doi:

https://doi.org/10.29244/jpsl.9.2.276-287

Ustaoglu, E., \& Aydınoglu, A. (2020). Suitability Evaluation of Urban Construction Land in Pendik District of Istanbul, Turkey. Land Use Policy, 99, 104783. Doi: https://doi.org/ 10.1016/j.landusepol.2020.104783

Utami, W. (2014). Ketersediaan Tanah bagi Masyarakat Rawan Bencana. BHUMI: Jurnal Agraria dan Pertanahan(40), 663-679.

Utami, W., Wibowo, Y. A., \& Afiq, M. (2019). Analisis Spasial untuk Lokasi Relokasi Masyarakat Terdampak Tsunami Selat Banten Tahun 2018. BHUMI: Jurnal Agraria dan Pertanahan, 5(1), 112-128. Doi: 10.31292/jb.v5i1.323

Zamroni, A., Kurniati, A. C., \& Prasetya, H. N. E. (2020). The Assessment of Landslides Disaster Mitigation in Java Island, Indonesia: a Review. Journal of Geoscience, Engineering, Environment, and Technology, 5(3), 129-133. Doi: https://doi.org/10.25299/jgeet.2020.5.3. 4676 